\title{
Gawad Plaridel Lecture 2018
}

Na. Jessica A. Soho

On 29 August 2018, the Gawad Plaridel, the highest award given by the University of the Philippines (U.P.) to outstanding media practitioners, was conferred by U.P. President Danilo Concepcion in the presence of U.P. Diliman Chancellor Michael L. Tan, U.P. College of Mass Communication (CMC) Dean Elena Pernia, and Professor Emeritus Nicanor Tiongson on Ms. Maria Jessica A. Soho.

The U.P. Gawad Plaridel 2018 was awarded to Soho for her uncompromising and unwavering integrity in her more than 30 years of service in broadcast journalism, maintaining the highest standards of excellence in broadcasting, and mentoring younger generations of broadcast journalists in the country. These are evidenced by the local and international awards acclaiming her programs as superior investigative and news programs and herself as outstanding host and news presenter, including six Readers Digest Asia Most Trusted News Presenter awards and the first George Foster Peabody Award given to a Filipino an outstanding professional life that has served as a model for the next generation of broadcast journalists

This issue of Plaridel publishes three documents relevant to the proclamation of Ms. Soho as 2018 Gawad Plaridel awardee: first, the official citation which enumerates and describes the achievements for which Ms. Soho is being recognized; second, an essay on the life and works of the awardee by Prof. Rachel Khan; and third, the Gawad Plaridel speech of the awardee. 


\section{The Gawad Plaridel 2018 Citation for \\ Ms. Maria Jessica A. Soho}

For being the driving force behind the excellent investigative reporting in GMA through investigative programs like Brigada and for advancing in-depth reporting through news magazine programs like her top-rating Kapuso Mo, Jessica Soho;

For initiating, together with another colleague, the well-regarded I-Witness: GMA Documentaries in 1999 and producing some of its most substantial and memorable episodes, like those on kidneys for sale and the plight of Filipino boxers;

For anchoring the long-running State of the Nation with Jessica Soho, a newscast program distinguished not only for its in-depth coverage but also for the insightful analyses by experts, of the most important news stories of the day;

For bravely and systematically covering dangerous but very significant assignments such as the 1986 EDSA Revolt, the Mount Pinatubo eruption, the various coup d'etat attempts against the Corazon Aquino administration, and the super typhoon Yolanda as well as foreign assignments like the war in Afghanistan and Pakistan;

For maintaining the highest standards of excellence in broadcasting, as evidenced by the local and international awards acclaiming her programs as superior investigative and news programs and herself as outstanding host and news presenter, including six Readers Digest Asia Most Trusted News Presenter awards and the first George Foster Peabody Award given to a Filipino;

For mentoring younger generations of broadcast journalists in the country, enabling them to diversify 
news programming and further developing their capacities for in-depth news reporting for broadcast; and

For her uncompromising and unwavering integrity that sought to implement the highest ethical standards in her more than 30 years of service in broadcast journalism, an outstanding professional life that has served as a model for the next generation of broadcast journalists.

The U.P. College of Mass Communication awards the U.P. Gawad Plaridel to Maria Jessica A. Soho this $29^{\text {th }}$ day of August in the year 2018 at the Cine Adarna, UPFI Film Center, University of the Philippines, Diliman, Quezon City.

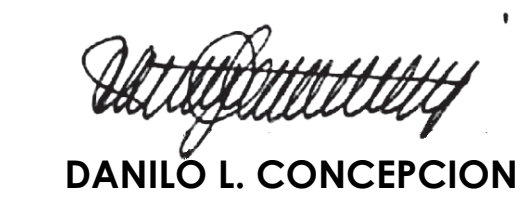

President, University of the Philippines

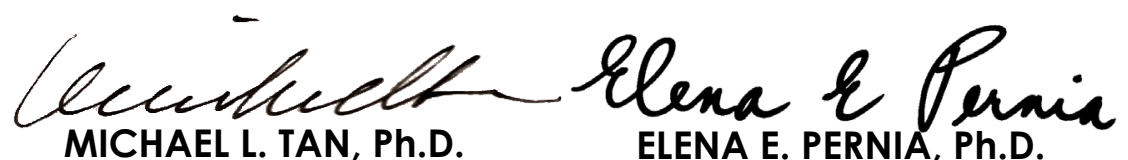

Chancellor. U.P. Diliman

Dean, U.P. College of Mass Communication 


\section{At the heart of Jessica Soho}

Rachel E. Khan, DPA

For eight consecutive years, Jessica Soho, has been named as the Most Trusted Filipino communicator by the international magazine Reader's Digest. This year, she became the first Filipino to be raised to the Hall of Fame for this category. Similarly, a recent survey by EON corporation on the People's Trust Index yielded the same results.

In an age of post-truths and fake news, being voted the "most trusted" Philippine communicator is not easy to come by. "Credibility," noted Jessica, "is due to hard work and after more than 30 years of being in the news business, I find that we still have to work hard to maintain it."

She currently hosts three

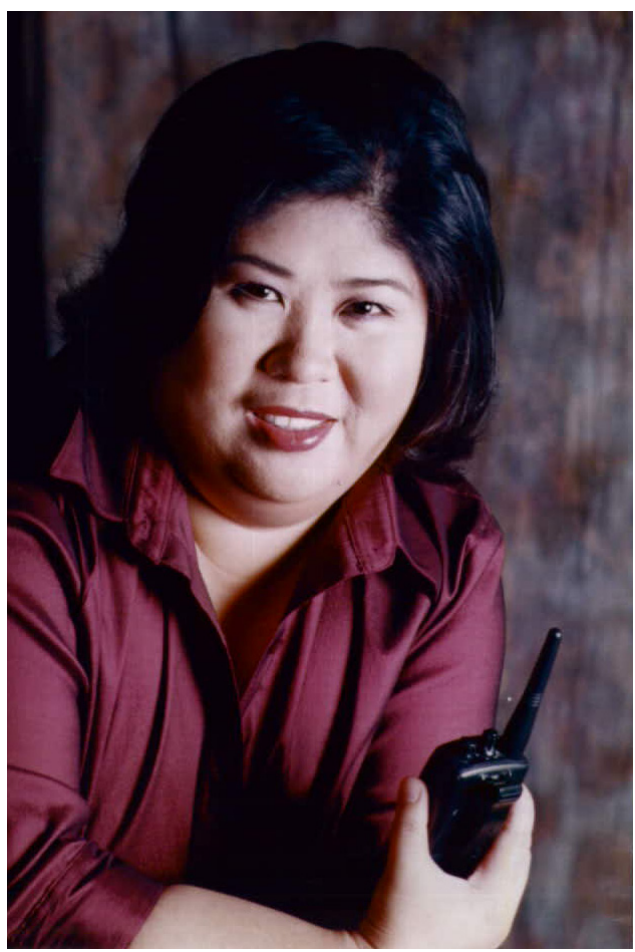
of GMA's public affairs programs: Brigada, which covers different news beats; State of the Nation with Jessica Soho, a fast-moving mix of news, entertainment and opinion; and, Kapuso Mo, Jessica Soho, which features human interest stories.

Jessica debunks the notion that broadcast news is glamorous. "I don't think about the glamor, I think about getting the story," says the GMA Network veteran.

Whether she is interviewing a head of state, a disaster victim or a military officer, the common thread of her news coverage is her ability to tell a story. "I am mindful that the story should always be about the people and events I cover and not the person covering them," she says.

\section{Storyteller}

Jessica Aspiras Soho was born in Agoo, La Union on March 27, 1964 to Abelardo Soho, a former government employee and the late Maura Aspiras 
Soho, an agriculturalist. She has a brother and two half-siblings from her father's second marriage. Her elementary and high school was spent at Christ the King College in San Fernando City, La Union.

Despite losing her mother to sickness when she was just eight years old, Jessica attributes her courage from her mother and her story-telling abilities from her maternal grandmother. Apo Itang Aspiras, who was a schoolteacher, was good at telling stories. "When I was at her (Apo Itang) house, I would sleep beside her and she would tell me stories about her life during the Japanese occupation, her life as a student, and how she became an educator," Jessica recalls. On the other hand, her mother's words had given her confidence. "Whenever I felt nervous, my mother would always tell me, kaya mo yan. You can face them. Give it all you've got," she says.

She notes that having grown up in the province and moving to the city for her college education had given her the needed exposure. "I think I had the best of both worlds. I grew up and experienced what it is like living in both urban and rural places. And I think it also gave me opportunities to meet all kinds of people," she says.

\section{Unplanned Career}

Jessica says that she did not plan to become a journalist-journalism found her.

"I was actually thinking of becoming a lawyer," she says. In fact, Jessica's original course at the University of the Philippines (UP) was political science. She shifted in her sophomore year. "For some reason Pol Sci had too many math courses, so I scouted for one that had only one math course and found Journalism," she recalls.

She says that back then none of her classmates would have guessed that she'd be the one of those who would have successful careers in journalism. In a recent gathering with UP CMC faculty, she relates that the late Louie Beltran, who taught the basic course on newswriting had said,"Iyan si Soho, I never expected her to make it because she was such a mouse in my class."

While she was rarely the outspoken one in her Journalism classes, Jessica says she was serious student; a fact confirmed by classmates like GMA Public Affairs head Marissa Flores. In college at the tail-end of the Martial Law years, Jessica credits her UP education for "where I am today." Jessica says UP helped her become independent. She also noted that the extracurricular activities such as the various symposia and other learning opportunities also helped "developed in her critical thinking and showed me that there are different pathways in life that one could take." In the CMC promotional documentary of its alumni, one of the personalities include Jessica Soho stating her student number. About this she says, "Like most UP 
alumni I know-with the exception maybe of 1 or 2, I have not forgotten my student number. UP makes sure you remember it for life. You are branded and numbered forever. Hindi po ako nahihiyang sabihin ang aking student

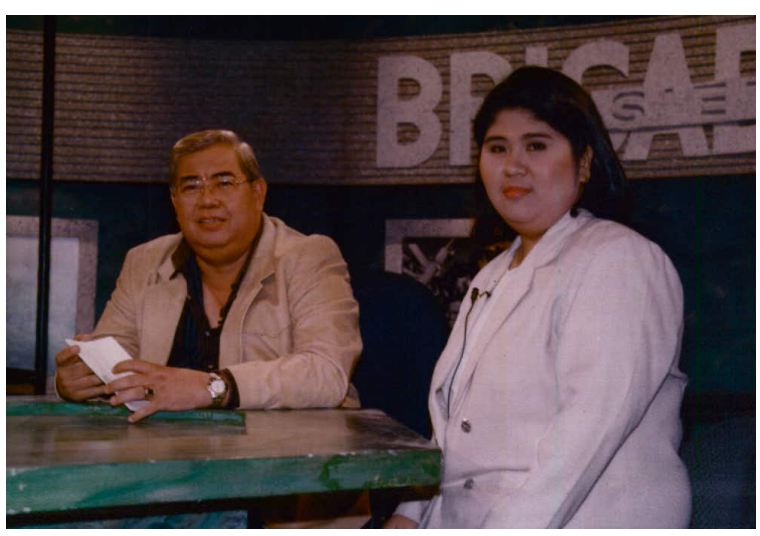
number even if it gives away my age."

After graduating at the age of 20 , she was a walk-in applicant at GMA following a tip by her professor, the late Louis Beltran, that there was an opening in the network for journalism graduates. "I was lucky because at the time they were looking for a female reporter, so even if I looked like a probinsiyana, I got the job," she says, adding, "I never planned to be a reporter. I just wanted to have a job. I was even willing to accept whatever job they would give me-production assistant, writer, phone operator-any work was okay with me as long as I was in."

She considered herself lucky because whenever a team was in need of a reporter, she was available in the office. When former desk editor Rey Vidal found out that she knew how to write news, she started reporting regularly. "My father was a solid GMA viewer, and the biggest fan of Tina MonzonPalma. But it never crossed my mind that I would someday be reporting the news in GMA and that Tina would call in my reports and say, 'Jessica Soho reports," she recalls.

However, her fascination for law continued even when she was already an established journalist. "I am fascinated by how lawyers think; how they can justify things that did not seem justifiable. It's this whole ability to use one's reasoning skills," she says. In fact, Jessica says she only gave up the idea of taking up law some five years ago. In 2015, Soho was given an honorary doctorate in humanities by the University of Northeastern Philippines during its 67th Commencement Exercises on April.

\section{True Grit}

In GMA, Jessica worked under the supervision of Tina Monson Palma. From her I learned that getting the story was more important that the supposed glamor of the job, Jessica says. "I was the reporter who was sent to cover for 
other reporters who were absent, or when there was no one else available to cover the event," Jessica recalls, adding, "I never said no or that I cannot, I always just covered what I was told to cover."

Less than a year into the job, she her first limelight moments covering the inauguration of the Light Rail Transit from Baclaran to Monumento and the Regent of Manila fire.

Her climb to being the most trusted communicator began

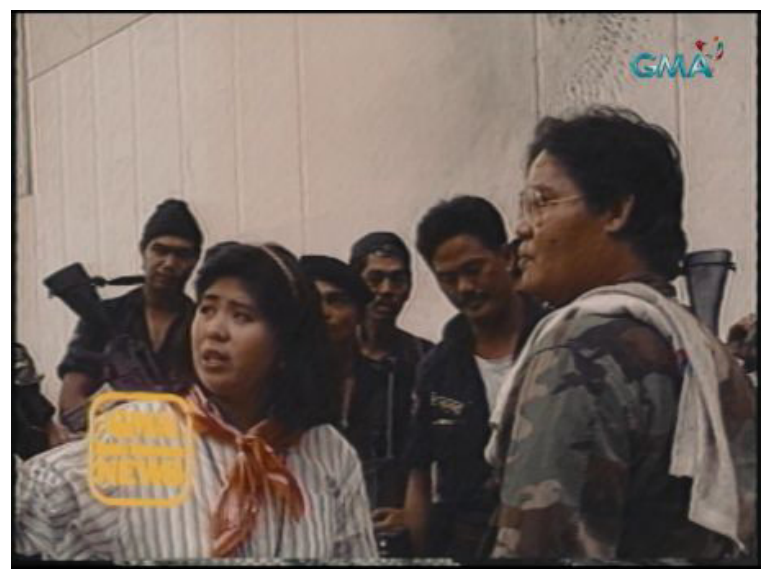

with EDSA I and her coverages of the coup d'etat attempts during the Corazon Aquino administration and her disaster coverages. She recalls being sent to cover EDSA I because she was simply available; other reporters were already in their beats. "I was sent to go to EDSA because I was the one available. While, we were there we got a two-way message saying that helicopters were on the way to shoot the protesters. We ran up the VV Soliven Building for cover and to get a good view of the people on EDSA from the highest floor and found the snipers of the rebel forces up there," she says.

Despite her youth and being female, she was soon assigned to the military beat when the previous reporter took ill. Being assigned to the military beat gave her the advantageous opportunity of being in the right place at the right time, although it also placed her in hazardous situations.

A story by Agnes de Guzman for the Philippine Daily Inquirer reports that Jessica gained significant audience attention with her coverage of the 1987 Typhoon Sisang. She quotes Jessica as relating their ordeal riding a Philippine Air Force helicopter to cover the rescue operations in Marikina, which was sunk in floodwater.

While, Jessica emphasizes that the reporter's job is to get the news and not become the news. It is hard not to become the news when one had a brush with death.

The first incident occurred on her $25^{\text {th }}$ birthday during her election coverage at the Pag-asa base on Spratlys Islands in 1989. On their way back to Puerto Princessa from the Spratlys Islands, the military plane she was riding with her crew along with Western Command Brig. General 


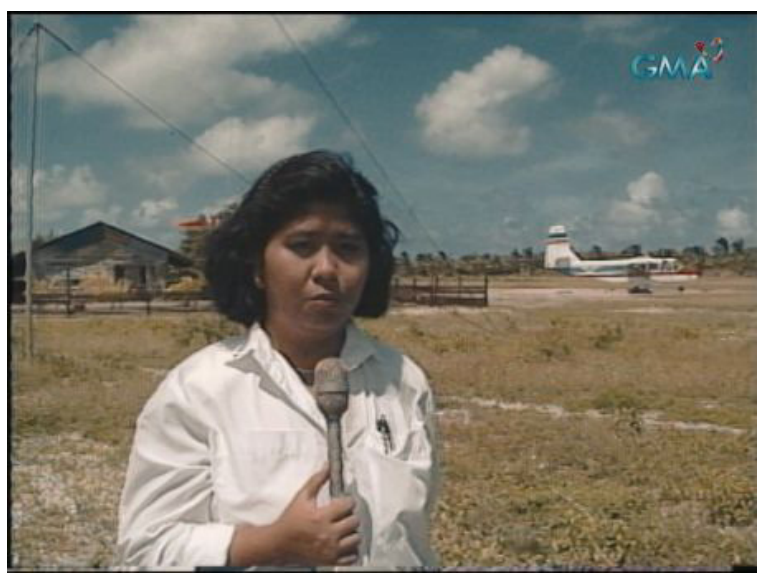

Napoleon Angeles had some engine trouble that resulted in the plane being lost at sea and almost running out fuel. Luckily, they were able to land on Ramos Island on the southernmost tip of Palawan. However, since they were stranded on the remote island in the days wherein wireless communication was still not available, no one in Manila knew where they were or if they were alive. It was only after sometime that General Angeles was able to find the few inhabitants of the island who had a pump boat that enabled him to go to the Balacbac Naval Base and arrange for a rescue. Meanwhile, because the plane had gone missing and it took them almost 48 hours to be rescued, some radio reports already announced that they were missing and most likely dead. One over eager radio report said that their plane "exploded and that there were no survivors."

Jessica was the first Filipino to bag the New York Film Festival Award for "Coverage of a Breaking Story" when, in 1990, she found herself with her crew were once in the thick of danger when covering the infamous hostage crisis in Cagayan Valley when Government troops clashed with supporters of a provincial Governor who took over a hotel in Tuguegarao; where the GMA crew happened to be billeted. While Jessica and her crew were soon set free, the tale tragically ended with the death of Brig. Gen. Oscar Florendo, head of the armed forces civil relations service, who attempted to arrest the rogue governor.

In 2002, Jessica had another brush with death when covering the demining operations in Baghram, Afghanistan, a village near a US military base. Jessica was interviewing one of the teams that were tasked with removing the land mines with an ambulance within camera distance as it picked up one of the injured deminers. When the ambulance was in the act of leaving, it drove over a mine and exploded. Luckily, the shards of the nearby blast did not reach Jessica Soho and her crew, but all the people in the ambulance died.

Despite the tragic event, she treasures trips like these. "I love Italy and the south of France but all these places are accessible to most people. 
But not all people will go to Afghanistan or in Peshawar, one of the most dangerous places in Pakistan," she says. Despite the tragic land mine blast, Jessica recalls Kabul in Afganistan fondly because of the colorful alley called Chicken Street, which was filled with attractive souvenir stores. "It was very quaint and it was interesting to go inside the shops," she says.

Apart from her many adventures, Jessica has also displayed her skill in in-depth interviewing as seen in her one-on-one interviews with the world's top leaders such as the US President Barrack Obama and the United Nations Secretary-General Ban Ki-moon.

\section{Untiring Dedication}

Apart from the Reader's Digest recognition, Jessica holds the distinction of being the most awarded broadcast journalist in Philippine history with two hundred fifty-three (253) local awards and thirty-two (32) international awards to date. Yet, she is still uncomfortable with receiving awards. "An award is additional pressure," she says, noting that it translate to a demand

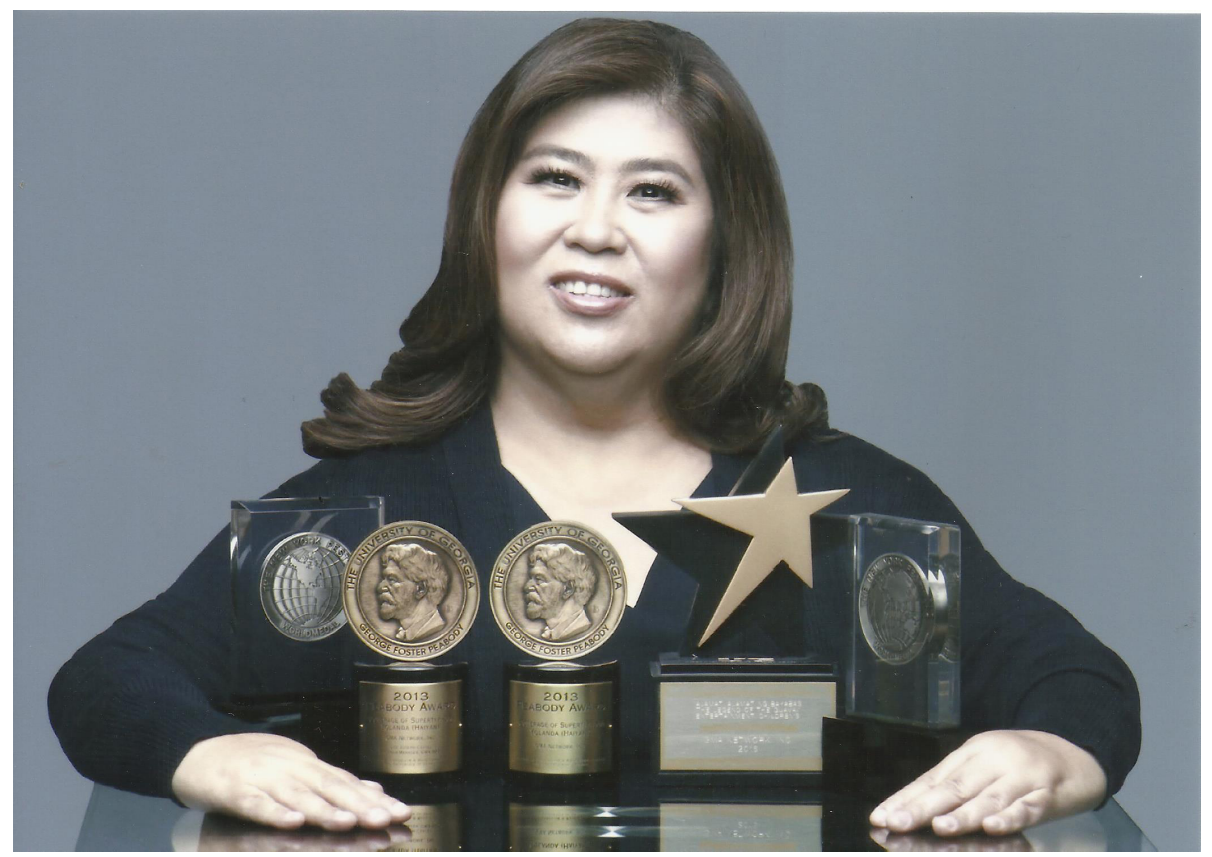

to maintain and even exceed the quality of the reportage.

At the same time, she noted that "hindi lang naman tayong nasa harap ng camera ang bumubuo ng storya (we are not the only ones involved in production)," she says, adding, "I believe that in each award, I represent the 
teams that gathered that story." Cameramen and crew who have worked with her concur that she never takes them for granted and that she does not have any airs despite her celebrity status.

As a broadcast journalist, Jessica was not content in just reporting the breaking news but is one of the pioneers in in-depth television news reporting. She is credited with being the brains behind i-Witness, the networks venture into investigative journalism for television.

When she proposed the show, she received a lot of opposition. "At the time, long form journalism was still unheard of in television. They said it would not rate or that no one would be interested," she recalls.

She was vindicated when one of the first stories on i-Witness earned Jessica the prestigious George Foster Peabody Award in 2000, a first for a Filipino journalist. This was the exposé on a thriving organ trade, entitled, "Kidneys for Sale," This ground-breaking documentary revealed that due to the increasing demand for kidney donors, agents were luring impoverished men, specifically in Brgy. Baseco in Tondo, Manila into 'donating' their kidneys for a promised Php70,000 to Php100,000.

Jessica later won that prestigious international award for other stories, such as the harrowing plight of Filipino boxers and more recently, for her Yolanda coverage. She has also been elevated by the Rotary Club of Manila to the Hall of Fame for TV journalists, and is a lifetime achievement awardee by the Philippine Movie Press Club for excellence in broadcasting. Aside from journalism awards, Jessica was also named one of the Ten Outstanding Young Men (1993) and the Ten Outstanding Young Women in the Nation's Service (2001) awards.

These days, she fosters the development of younger broadcast journalists. Within the GMA Network, she found herself in various management positions from being appointed as Section Head of the News Production in 1999; Production News Manager in 2000; Acting News Director in 2002; and finally as Vice President for News in 2004. Jessica sees these posts not as promotions, "I have been given so many opportunities and I felt that I owed them these services as payback," she says, adding, "kahit mas mahirap mag-manage ng tao (even if managing people is a hard job)."

According to GMA reporters, they learn a lot from her and she is "very demanding." At the same time, reporters describe her as "hindi madamot (generous)" with her knowledge and encouragement. In fact, the reporters are given more airtime in the show Brigada, a show she also conceived and where she serves as its host. Jessica for her part says she is demanding because "from the time I was a young reporter, I never said no to an assignment. If I was told to cover something, I do it and I expect no less from the journalists 


\section{I am training."}

These days, Jessica is "less of a terror" in the newsroom after retiring as Vice President for News in July 2014. Now, she even has the time to join the network staff for Zumba. However, she remains as GMA network's icon with her three top-rating shows, which now includes a public affairs cum entertainment show, Kapuso Mo, Jessica Soho, that allows her to explore the lighter side of life and not just the tragedies and serious news for which is known for. But even in this, she shows a level of excellence that induced Liam Bartlett of Australia's 60-minutes show, to dub her as the "Oprah Winfrey of the Philippines."

Whether pursuing a hard-hitting story or an inspiring light-hearted one, Jessica says the bottom line is that the job of a journalist is "to tell a story and that story is never about us."

\section{\#\#\#}

RACHEL E. KHAN is a Professor of Journalism at the College of Mass Communication at the University of the Philippines, where she is currently serving another term as Chair of the Journalism Department. She holds a Doctorate degree in Public Administration, an MS in Journalism from Columbia University, USA, and a BS in Economics from the University of the Philippines. Prior to joining the academe, she was a multi-award-winning journalist working for BusinessWorld, a leading business daily in the Philippines. She is also the author of several textbooks on media literacy and journalism. 


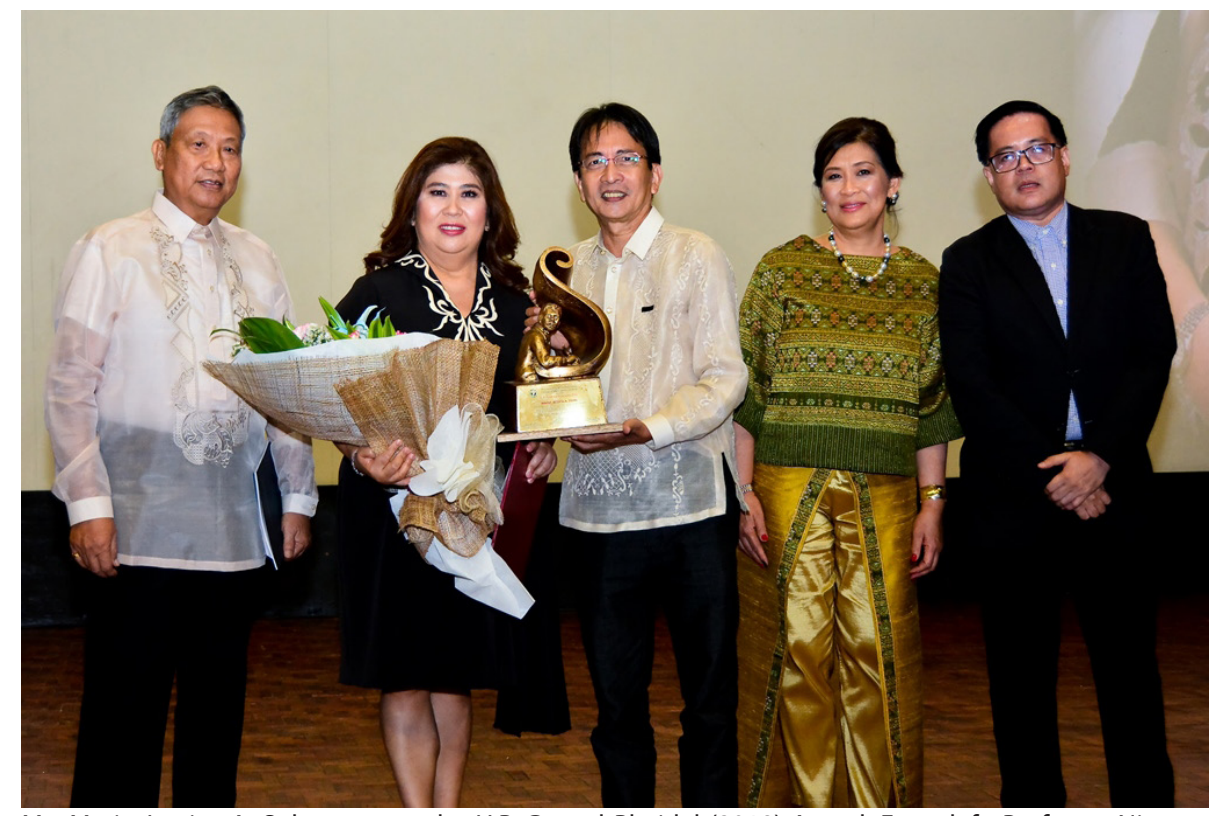

Ms. Maria Jessica A. Soho accepts the U.P. Gawad Plaridel (2018) Award. From left: Professor Nicanor Tiongson, Ms. Jessica Soho, Diliman Chancellor Michael Tan, CMC Dean Elena E. Pernia, and U.P. President Danilo Concepcion (Photo courtesy of Alex NPTamayo and the Office of Extension and External Relations)

\section{Gawad Plaridel 2018 Prepared Speech*}

Maria Jessica A. Soho

Magandang hapon po sa inyong lahat.

There is one question that's often asked in our newsroom, then and now, especially to our reporters and news teams, going or returning from the field: What is YOUR story? Anong istorya o balita mo?

Na para bang to everyone in the newsroom, that was all that mattered. Your worth or market value for the day. No "How are you?" or "Are you ok?" It is an accepted fact among journalists that you're only as good as your last story.

Great if you had a scoop or an exclusive or you covered something important. Sorry ka na lang if your story did not amount to much although there is always another day to make up for it.

These days a lot of people are asking that same question, even outside the newsroom and even among non-journalists. What is your story, your truth or your messaging or your narrative? Mine is actually very simple. 


\section{Promdi or a small town girl who made good.}

As one of my cameramen used to say, pinabili lang ng suka, naging reporter $n a$. Which was true to a certain extent because I did not plan on becoming a journalist. Journalism, as a course in college, was just an escape from the 12 units of Math required in Political Science.

\section{Babala, mga bata. Wag gagayahin. Lubhang mapanganib!}

Had it not been for Professor Louie Beltran who inspired us with stories about his exploits as a journalist and who brought to class excellentlywritten news articles from the New York Times and who also just happened to casually mention to our class one day that his friend, Tony Seva of GMA News, preferred to hire journalism graduates even for broadcasting-I will not be here today.

Today I stand before you as you honor me and my life's work when really, the credit should also go to everyone who has helped me in my more than 33 years in broadcast journalism.

\section{Napakarami po nila.}

From my earliest mentors in the newsroom - reporter and deskman Rey Vidal, audiovisual head Steve Serna and my cameramen; to those who taught me how to connect better to a wider set of audience-Bobby Barreiro and Tony Tuviera; to Atty. Felipe Gozon for putting me on primetime and for all the help; Jimmy Duavit and Felipe Yalong for all their love and support and to all my colleagues in GMA News and Public Affairs including the current and former staff for Kapuso mo, Jessica Soho, BRIGADA, and State of the Nation with Jessica Soho.

Thank you very, very much.

Wala ako rito, kung hindi dahil sa inyo.

I started out tabula rasa, an empty sheet, walang alam bukod sa makapal ang mukha at nakahandang gawin ang lahat magkatrabaho lang.

I would not have minded had they made me answer the telephones or make coffee or man the teleprompter. There was just so much to learn and it was all so very exciting!

And now, back to THE story.

I cannot over-emphasize that enough. 
Because THAT is what we are really here for; the reason for our being, if you will, and what we all should continue working hard for.

To get the story and to keep getting it right.

Many journalists have died in pursuit of the story. Tyrants resort to killing hoping they'd kill the story too. Leaders in the Philippines and even in the United States have fallen because of the story.

It sounds so basic and fundamental but the story is very powerful! I've had my share of fighting battles to defend the story.

Some were won, some were lost but life goes on.

Some people may think there is a dichotomy or a difference in being a Filipino and being a journalist but I don't. I am both. I am a Filipino journalist and I am not torn between public interest and the truth. I do not see any conflict there because at the bottom of it all is the story-the truth. The story can never be changed nor revised, even if memories are short.

What happened, happened!

Pagbali-baligtarin man natin ang mundo. Huwag na nating kumplikahin pa at pahirapan. And I have Tina Monzon Palma to thank for, for this most important lesson that saw me through some pivotal crossroads in my career. She was the one who hired me and it was also through her example and courage that my newsroom contemporaries and I learned the value of upholding the truth, no matter what.

To stand your ground, no matter the consequences.

To defend the integrity of the story.

And we need more of this in these perilous times. When journalism and journalists are under attack by those who try to discredit us and undermine our credibility. In a manner both cunning and brillant, let's grant them that-by mirroring us and our content and passing those as news when clearly it's not. I say fake news is nothing more than a deliberate distortion of the truth and of reality.

Some people can't handle the truth so they make their own or their version of reality which is really nothing more than falsehoods or lies. And so today we hear of post-truths, alternative realities and the latest-truth isn't truth-at a time when we're supposed to be knowing better and communicating more. 
The scary part is fake news has been weaponized. It has become so powerful it is believed to have influenced the outcome of the US elections, no less!

What could be worse than that?

Imagine, the most powerful person of not only the most powerful country but the whole world, a beneficiary of fake news!!!

How do we fight it?

Simply by being more discerning. Get your news from trusted sources, not primarily from your own news feeds. Don't believe anything just because it's been repeated or retweeted or liked a million times.

It is never a popularity contest.

The story and the truth is determined NOT by algorithms or the number of posts, likes,tweets or engagements but by facts and facts alone. Don't assume something as true just because it's been said or passed on many times. And please, fact-check. You have the tools and the apps and all you need is the click of a button or a swipe of a finger.

Let's all dig deeper, work even harder. The only antidote to fake news is the truth-the story. Istorya pa rin. Iyung talagang nangyari. Diyan lang naman nagkakatalo lagi.

Professor Rachel Khan has asked me to include in my speech or lecture about the importance of having the right values.

Kaya pasensya na kayo, mga millennials diyan alam ko you don't like being preached to. But I think it's important that we all do our share and because this is supposed to be a lecture too, I don't mind if you take down notes.

Here goes:

For those of you wanting to join us, in broadcast or print or digital-I think it is very important for you to have the right values. The technical stuff you need to learn and store in your head but the right values, you need to live by and encode in your DNA.

Importante siempre ang laman ng utak, pero mas lalung mahalaga ang laman $n g$ puso. The three functions or purposes of communication-to inform, educate and enlighten-go hand in hand. It's a package deal and ideally should not be taken separately. 
Just as the University's code of honor and excellence, as Professor or Tita Winnie Monsod has so aptly put it, should also be lived by together and in THAT order!

Honor before excellence.

Excellence alone will not suffice. It needs honor and honor should be first! We/You don't have that right if we/you are no better than the purveyors of fake news or the liars and the propagandists. If there is one side journalists or students of journalism should side with-that is the the story and its integrity, the truth.

And please indulge me more, minsan lang naman ito, to also share some more life lessons:

1. Read, read, read. Do your homework.

2. Because, substance is key! Content will always be king or queen! The Internet is only the platform or the distribution highway.

3. The story is the story! It is never about you! It should not be about you. Unselfie. You will never ever know enough so to learn more, be humble.

4. Ask the tough questions; not the motherhood or generic ones.

5. Listen well.

6. Failure is a prerequisite to learning and success! Prepare for it and once it happens, get back on your feet, fast and learn good. There are no mistakes in life, only lessons. Positivize your hugot.

7. Journalists should not have comfort zones! Every day, every story is different. Stress, sleep deprivation, missed meals, cancelled or shortened vacations are guaranteed. Deadlines rule!!!

Journalism is never easy; it is a far bigger cause than any of us. Go for the terror teachers! They're really the best!

8. Do the right thing. Even when all else fails and even if you're the only one doing it. As our election coverage battlecry goes, and may I claim credit for it, Dapat Tama!

Sa totoo lang, when I was asked to give my mantra in life for today's souvenir program, it did not come easy.

In the end, I settled for "Every story is important"-which is really what I live by. 
Every story is important. A small, minor story could lead to a major expose!

"Kidneys for Sale," my documentary on poor Filipinos who sold their kidneys, started out as a mere follow-up story to a crime. It was not a major story; it was in the inside pages. A prominent kidney doctor was ambushed; he survived but not his daughter who was with him in the car. When I went to the police station to get an update; the station commander turned out to be an old acquaintance from my years of covering the military and the police. Next thing I knew, he was showing me pictures of about a dozen men from Baseco compound in Tondo, with diagonal cuts on the side of their torsos where one of their kidneys was harvested from. You connect the dots, as they say, but first you have to find those dots and ask the right questions to the right people.

Looking for missing people was just an out-of-the-box idea in Jessica Soho Reports, our late-night news magazine program before they put us in primetime with Kapuso Mo, Jessica Soho. We couldn't brainstorm good topics on a particular week when there wasn't much breaking news. And so I asked why don't we do a story about missing kids? The following day, after our episode aired-the three missing kids we featured were all happily reunited with their families.

If we harness television's immense power, reach and impact, wala pang social media nun, you can help people solve their problems!

From that episode was born a weekly program locating missing people-Sana'y Muling Makapiling followed by Reunions with an average of 3 families reunited per week or a total of 800 families reunited in a span of 6 years.

The same story concept has been carried on in Kapuso Mo, Jessica Soho. KMJS reunited Joel and his biological mother after more than three (3) decades! Joel was lost when he was 5 and adopted and brought to Australia by his adoptive parents.

Bryan, the OFW from Italy was likewise reunited with his biological mother, 38 years after he was given up for adoption. A staff member put it all together when he/she said: "more than the ratings, we're gaining points in heaven."

To be a journalist is to be a truth-seeker.

Someone said that to seek the truth is to shine the light even on the darkness of our soul. We need to balance this by somehow keeping the hope 
alive. By capturing a reality where not only the bad happens but the good too. The world may be broken but it can be fixed and the good people still outnumber the bad.

Our generation and those before us have failed to solve many of our problems. But I am hopeful you, our millennials, will do better. With so much power in your hands and your limitless potentials, please turn things around! Make this world a better place, no matter how much of a cliché that sounds.

Use your so-called "sense of entitlement" to demand and make possible better things for your generation and those to come. They say your generation is more inclusive and more open to possibilities. That should also mean less barriers, less walls to overcome; that you will be more accepting of others and to stop the spread of hatred not only on social media.

As we say in UP, kung hindi tayo/kayo, sino? Kung hindi ngayon, kelan? I say, that should be the story of every Iskolar ng Bayan. 